\title{
El poder normativo local y la crisis de la ley
}

\section{Local regulatory power and the crisis of the law}

\author{
Tomás Cano Campos \\ Universidad Complutense de Madrid (España) \\ ORCID: https://orcid.org/0000-0003-2268-9681 \\ tcano@der.ucm.es
}

\section{NOTA BIOGRÁFICA}

Catedrático de Derecho Administrativo de la Universidad Complutense de Madrid. Realizó los tres primeros años de la Licenciatura en la Universidad de Barcelona y la concluyó en la Complutense de Madrid. Es Doctor en Derecho por la Universidad de Bolonia. Sus líneas de investigación se centran en la invalidez de los actos y de las normas, las sanciones administrativas, los contratos públicos, la responsabilidad patrimonial de la Administración, el tráfico, los transportes y la movilidad.

\section{RESUMEN}

El presente trabajo analiza la evolución del poder normativo de los entes locales en estos cuarenta años de régimen local democrático en España. Lo hace centrándose en torno a tres ideas esenciales: la complejidad del sistema actual frente a la simplicidad del anterior; el incremento o ampliación de las materias de las que se ocupan las normas locales, especialmente las ordenanzas municipales; y, sobre todo, la posición singular de tales normas en el sistema de fuentes, en particular por su peculiar relación con la ley.

\section{PALABRAS CLAVE}

Poder normativo local; ordenanzas municipales; vinculación a la ley; reserva de ley; crisis de la ley.

\begin{abstract}
This paper analyzes the evolution of the regulatory power of local authorities in these forty years of local democratic government in Spain. It does so by focusing on three essential ideas: complexity of the current system versus the simplicity of the previous one; increase or expansion of the matters that local regulations deal with, especially municipal ordinances; and, above all, the unique position of such norms in the system of legal sources, in particular because of their peculiar relationship with the law.
\end{abstract}

\section{KEYWORDS}

Local regulatory power; municipal ordinances; bonding to the law; reservation of law; crisis of the law.

\section{SUMARIO}

1. INTRODUCCIÓN. 2. DIVERSIFICACIÓN, COMPLEJIDAD Y AMPLIACIÓN DEL PODER NORMATIVO LOCAL. 2.1. LA CRECIENTE DIVERSIFICACIÓN Y COMPLEJIDAD DEL PODER NORMATIVO LOCAL. 2.2. LA EXPANSIÓN MATERIAL DE LAS ORDENANZAS MUNICIPALES. 3. LA POSICIÓN SINGULAR DE LAS ORDENANZAS EN EL SISTEMA DE FUENTES: ¿VINCULACIÓN NEGATIVA A LA LEY? 3.1. LA POSICIÓN SINGULAR DE LAS ORDENANZAS Y SUS MANIFESTACIONES MÁS IMPORTANTES. 3.2. LA VINCULACIÓN NEGATIVA A LA LEY Y SU FUNDAMENTO. 3.3. VINCULACIÓN A LA LEY 
Y AMPLITUD DEL CAMPO DE ACCIÓN DE LAS ORDENANZAS MUNICIPALES. 3.4. ÁMBITOS QUE DESMIENTEN LA VINCULACIÓN NEGATIVA DE LAS ORDENANZAS A LA LEY. 4. LA FLEXIBILIZACIÓN DE LA RESERVA DE LEY. 4.1. SECTORES EN LOS QUE SE HA FLEXIBILIZADO LA RESERVA DE LEY: LOS TRIBUTOS LOCALES Y LAS SANCIONES ADMINISTRATIVAS. 4.2. LOS ARGUMENTOS ESGRIMIDOS PARA FLEXIBILIZAR (AÚN MÁS) LA RESERVA DE LEYY SU FALTA DE CONSISTENCIA. 4.3. LA FLEXIBILIZACIÓN DE LA RESERVA DE LEY EN EL ÁMBITO SANCIONADOR Y SU CARÁCTER INNECESARIO. 4.4. EL PODER DE ORDENANZA Y LA CRISIS DE LA LEY. BIBLIOGRAFÍA.

\section{INTRODUCCIÓN}

Si hubiera que sintetizar en sólo tres frases la evolución del poder normativo de los entes locales en estos cuarenta años de régimen local democrático en España podría hacerse del siguiente modo: complejidad del sistema actual frente a la simplicidad del anterior; incremento o ampliación de las materias de las que se ocupan las normas locales, especialmente las ordenanzas municipales; y, sobre todo, posición singular de tales normas en el sistema de fuentes, en particular por su peculiar relación con la ley.

En las páginas que siguen voy a analizar la evolución de la potestad normativa local durante estos cuarenta años apoyándome en esas tres ideas centrales. Pero me voy a ocupar principalmente de la potestad normativa de los Municipios, que es la que mas claramente presenta esas características y la que ofrece más problemas desde el punto de vista jurídico. Aunque examinaré los tres aspectos referidos, centraré sobre todo mi atención en la posición singular de las ordenanzas municipales en el sistema de fuentes y, en particular, en sus relaciones con la ley, que es el tema en el que las discrepancias doctrinales y las oscilaciones en la jurisprudencia han sido mayores en estos últimos años.

\section{DIVERSIFICACION, COMPLEJIDAD Y AMPLIACIÓN DEL PODER NORMATIVO LOCAL}

\subsection{La creciente diversificación y complejidad del poder normativo local}

La aprobación de la CE y el reconocimiento en ella de la autonomía local han supuesto una clara tendencia hacia la diversificación y complejidad del ordenamiento local, superando así la concepción plana, uniforme y mononormativa que lo ha caracterizado desde los inicios mismos del constitucionalismo en el siglo XIX². Así, frente a la homogeneidad y simplicidad del poder normativo local en la etapa anterior, es evidente que dicho poder, y el ordenamiento en que se encuadra, resulta hoy mucho más complejo, diverso y plural.

La complejidad comienza ya con la propia ordenación de las disposiciones reguladoras del régimen local, esto es, con todo el entramado de normas que componen el orden normativo o sistema de fuentes del Derecho local (la Constitución, la Carta Europea de la Autonomía Local, el Derecho de la Unión Europea, los Estatutos de Autonomía, las leyes y reglamentos estatales y autonómicos, las propias normas locales) y los principios de articulación entre unas y otras, cuestiones estas de sumo interés pero en las que ahora no procede entrar $^{3}$.

Centrándonos en las normas dictadas por las propias entidades locales, la potestad normativa no sólo se predica de los Municipios sino también de las Provincias y de las Islas [art. 4.1.a) LBRL], si bien la relevancia de su poder normativo (por la índole de las competencias que ostentan) y su problemática (porque sus normas no emanan -como la de aquéllos- de un órgano con legitimación democrática directa) es mucho menor. Además, según el art. 4.2 LBRL, las leyes de las CC.AA. también pueden atribuir potestad normativa a otros entes locales como las entidades menores, las comarcas, las áreas metropolitanas y las demás entidades locales ${ }^{4}$.

Proyecto de Investigación del Ministerio de Economía y Competitividad (MINECO/FEDER) DER 2015-65.524-R y Grupo de Investigación 931.089 de la Universidad Complutense de Madrid. El presente texto constituye una versión ampliada de la ponencia presentada en el Seminario Cuarenta años de Régimen local democrático en España, celebrado el 24 de octubre de 2019 en el INAP

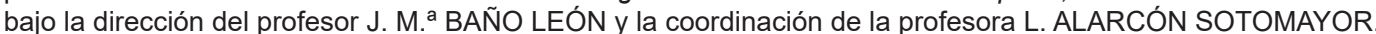

2 MUÑOZ MACHADO, S. (2015: 228-229).

3 El estudio más completo y sugerente sobre el tema es el de VELASCO CABALLERO, F. (2009). Vid. También el importante estudio introductorio de BAÑO LEÓN, J. M. a (2011: 643 y ss.).

4 Así lo hace, por ejemplo, el art. 4.2.a) de la Ley 8/1999, de 28 de abril, de Comarcas de la Comunidad Autónoma de Cantabria, y el art. 3.2.a) del Decreto Legislativo 1/2006, de 27 de diciembre, del Gobierno de Aragón, por el que se aprueba el Texto refundido de 
En el ámbito estrictamente municipal, en algunos Municipios (por ejemplo, en el de Barcelona), ya no sólo aprueba normas el Pleno, sino también la Comisión de Gobierno y el Alcalde ${ }^{5}$. En otros muchos Municipios han aumentado los órganos que participan activamente en la elaboración de las normas locales fruto de la complejidad de la propia organización municipal. Por ejemplo, en los Municipios de gran población, la Junta de Gobierno aprueba los proyectos de ordenanzas y reglamentos (art. $127 \mathrm{LBRL}$ ). Por último, en todos los Municipios se han establecido especialidades materiales y procedimentales para algunas normas aprobadas por el Pleno del Ayuntamiento (reglamentos, ordenanzas generales, ordenanzas fiscales, presupuesto, planes urbanísticos, etc.), lo que ha dado lugar a una diversificación de las formas normativas locales.

Se habla así de una diversidad de formas de ejercicio del poder normativo local, de un verdadero subsistema normativo integrado por una pluralidad de tipos que ocupan posiciones diferenciadas en su interior y que se relacionan entre sí por diversos principios (jerarquía, competencia, procedimiento). Pero, no sólo se han visto incrementados y enriquecidos los criterios de ordenación entre las propias normas locales, sino también los principios que rigen las relaciones entres ellas y las demás normas del ordenamiento autonómico y estatal.

A todo ello se ha unido el rechazo frontal a equiparar las ordenanzas con los reglamentos gubernativos y la inadecuación del esquema tradicional ley-reglamento para explicar las relaciones de las ordenanzas con la ley en nuestro ordenamiento actual, ya que las ordenanzas son normas que se fundamentan en la autonomía local constitucionalmente garantizada (arts. 137 y 140) y emanan directamente de un órgano representativo cuyos miembros gozan de legitimidad democrática directa, lo que reforzaría aún más esa singularidad de las ordenanzas municipales en nuestro sistema de fuentes ${ }^{6}$.

Todo esto es cierto y resulta evidente que estamos ante un subsistema normativo diferenciado y singular. Pero conviene no olvidar que se trata, en todo caso, de un subsistema encuadrado en otro superior que fundamenta su propia existencia y enmarca su actuación. Además, ese subsistema normativo no presenta las mismas relaciones con el ordenamiento estatal y autonómico que las que éstos presentan entre sí, regidas fundamentalmente por el principio de competencia, aunque también por el de prevalencia y supletoriedad. De modo que, el local es, en efecto, un ordenamiento singular pero sus normas están infraordenadas a las leyes del Estado y a las de las CC.AA. (en función de la materia de que se trate) y, por tanto, se rigen respecto de ellas por el principio de jerarquía normativa, principio que se inferiría del sometimiento pleno a la ley y al Derecho de la Administración (que es lo que son las Entidades locales) que consagra el art. 103.1 de la $\mathrm{CE}^{7}$.

\subsection{La expansión material de las ordenanzas municipales}

Junto a esa apertura a la diversificación de las normas municipales y a los criterios de ordenación entre ellas, también hay una tendencia clara a la ampliación de las materias de las que se han ocupado en estos años las ordenanzas municipales. Son muchas las manifestaciones de esta tendencia, por lo que sólo mencionaré algunas de las materias más relevantes.

En primer lugar, cabe destacar las ordenanzas de convivencia ciudadana o de civismo, que, dada su generalidad, afectan a numerosos ámbitos o sectores (seguridad, mendicidad, prostitución, limpieza, contaminación, etc.) e inciden directamente sobre la libertad genérica de los ciudadanos que reconoce la CE (arts.

la Ley de Comarcalización de Aragón, que atribuyen potestad reglamentaria y de autoorganización a las Comarcas; o el art. 55 de la Ley 2/2003, de 11 de marzo, de Administración Local de la Comunidad de Madrid, cuando dispone que las Mancomunidades son titulares de las potestades administrativas previstas en el art. 4.1 de la LBRL.

5 Vid. la Ley 22/1998, de 30 de diciembre, del Parlamento de Cataluña por la que se aprueba la Carta Municipal de Barcelona, que prevé reglamentos y ordenanzas del Pleno, decretos de la Comisión de Gobierno, decretos de Alcaldía, bandos del Alcalde, etc. Sobre el tema, vid. el completo y exhaustivo estudio de GALÁN GALÁN, A. (2010).

6 Sobre ello, entre otros, PAREJO ALFONSO, L. (1998: 80 y ss.); GALÁN GALÁN, A. (2001); JIMÉNEZ ASENSIO, R. (2005: 3637); VELASCO CABALLERO, F. (2009: 235 y ss.); MUÑOZ MACHADO, S. (2015: 273 y ss.).

7 VELASCO CABALLERO, F. (2009: 292). REBOLLO PUIG, M. (2019: 263-264) habla de supremacía de las leyes. Pero, en mi opinión, no hay problema alguno en hablar de jerarquía entre normas de diferentes ordenamientos ya que el concepto de jerarquía no es unívoco y las normas se relacionan por varios vínculos de jerarquía (estructural o formal, material, lógica y axiológica). Sobre el tema, en el que ahora no procede detenerse, GUASTINI, R. (2010: 242 y ss.); FERRER BELTRÁN, J. y RODRÍGUEZ, J. L. (2011: 136-140 y 176-185); PINO, G. (2010: 40 y ss.). Por lo demás, el que las ordenanzas no sean reglamentos ejecutivos de las leyes estatales y autonómicas, no quiere decir que no estén infraordenadas a ellas. Otra cosa son las relaciones de las ordenanzas con los reglamentos estatales y autonómicos, que vienen determinadas por la ley con arreglo a varios principios. Sobre el tema, VELASCO CABALLERO, F. (2009: 283 y ss.). 
1 y 10.1) al regular y ocuparse de numerosos comportamientos individuales y colectivos en tales ámbitos ${ }^{8}$. Tales ordenanzas han sido alabadas por unos, por considerarlas absolutamente necesarias para hacer frente a numerosos problemas, y cuestionadas por otros, en particular por su discutible oportunidad, por la dudosa competencia municipal para regular determinadas conductas y por la paradoja de que, en algunos aspectos, pueden acabar con el civismo que pretenden proteger y fomentar ${ }^{9}$.

También cabe citar las ordenanzas sobre el uso del burka o la niqab en los espacios públicos municipales, que a veces se desgajan de las anteriores y son dictadas por los Ayuntamientos sobre la base de sus competencias en materia de «seguridad en lugares públicos» (competencia que la Ley 27/2013, de 27 de diciembre de Racionalización y Sostenibilidad de la Administración Local ha sustituido por la de "policía local»), aunque estas ordenanzas plantean menos problemas desde el punto de vista del principio de legalidad por cuanto que se refieren al acceso a locales municipales destinados a un servicio público ${ }^{10}$.

Algunos Municipios han aprobado igualmente ordenanzas específicas sobre contaminación acústica, electromagnética y lumínica, que tratan de proteger la salud y los derechos que garantiza el art. $18 \mathrm{CE}$ (ordenanzas tuitivas), en un momento en el que ni la normativa estatal ni la autonómica se habían ocupado del tema ${ }^{11}$. En este mismo ámbito también cabe destacar las ordenanzas sobre antenas de telefonía móvil, que suelen imponer medidas adicionales de protección respecto de las previstas en la normativa estatal, por lo que su legalidad no plantea problema alguno y ha sido confirmada por el Tribunal Supremo en diversas sentencias ${ }^{12}$.

En el ámbito del medio ambiente también cabe citar las ordenanzas sobre olores, desechos y vertidos, también dictadas al amparo de las competencias de los Municipios en dicho ámbito (art. 25.2. LBRL), que afectan o inciden en derechos como el de propiedad o la libertad de empresa pero que el TS ha considerado que tienen en cobertura en la legislación de aguas estatal y en las leyes autonómicas de protección medioambiental ${ }^{13}$.

Las ordenanzas municipales sobre protección y tenencia animales de compañía y peligrosos, relacionadas con las competencias de los municipios en materia de salubridad pública, tranquilidad ciudadana y medio ambiente urbano, son otro claro ejemplo de la ampliación material de la potestad normativa municipal en estos años.

También pueden citarse en la misma línea de expansión las modernas ordenanzas de movilidad, que sustituyen a las tradicionales de tráfico y circulación vial. Se trata de normas cada vez más extensas (algunas desmesuradamente amplias, como la de Madrid que tiene 250 artículos y varios anexos), que tratan de acercarse al fenómeno de los desplazamientos en las áreas urbanas desde la perspectiva más amplia e integral de la movilidad sostenible. La Ley de Racionalización y Sostenibilidad de la Administración Local ha llevado a cabo en este ámbito un cambio importante, pues la redacción originaria del art. 25.2 de la LBRL atribuía a los Municipios competencias en materia de «b) Ordenación del tráfico de vehículos y personas en las vías urbanas», mientras que ahora el apartado g) de dicho precepto habla de «Tráfico, estacionamientos de vehículos y movilidad».

Por último, cabe destacar también el considerable incremento en todas ellas de su régimen sancionador como consecuencia de la flexibilización en esta materia de la reserva de ley que consagra el art. 25.1 de la CE. El tema y su problemática se analiza más abajo al estudiar la modulación de la reserva de ley en dicho ámbito.

La proliferación de ordenanzas municipales en estos y otros muchos sectores que se podrían citar (aprovechamiento de la energía solar, gestión y control de licencias, prevención de incendios, ocupación de la vía pública con contenedores, reparto de publicidad y difusión de octavillas en la vía pública, venta ambulante y mercadillos, instalación y funcionamiento de actividades hoteleras, establecimientos de tatuajes, etc.) ha supuesto una clara incidencia o afección en diversos derechos fundamentales reconocidos por la

\footnotetext{
8 Seguramente la más importante, y sin duda la que ha servido de modelo a casi todas las demás, es la de Barcelona. Sobre ella, vid. JIMÉNEZ ASENSIO, R. (2005: 29 y ss.); PEMÁN GAVÍN, J. (2007: 12 y ss.).

9 CASINO RUBIO, M. (2013: 1 y ss.). Se muestra crítica también, sobre todo por el amplísimo régimen sancionador que incorporan, ALARCÓN SOTOMAYOR, L. (2019: 288 y ss.).

10 Aunque el TS no siempre lo ha entendido así al considerar que se vulnera la libertad religiosa del art. $16.1 \mathrm{CE}$. Vid. su Sentencia de 14 de febrero de 2013 (rec. cas. 4.118/2011), sobre la Ordenanza de Civismo y Convivencia del Ayuntamiento de Lleida de 8 de octubre de 2010, que se cita más abajo.

11 DOMÉNECH PASCUAL, G. (2006: 621); ORTEGA BERNARDO, J. (2014: 55 y ss.)

12 SSTS de 17 de noviembre de 2009 y de 6 de abril de 2010, entre otras. Sobre el tema, EMBID IRUJO, A. (2010: 760$)$.

13 Sobre el particular, CASADO CASADO, L. (2007: 279 y ss.); ORTEGA BERNARDO, J. (2014: 121 ss.).
} 
CE (arts. 16, 18, 25.1, 33, 38, etc.), incidencia que en muchas ocasiones no ha sido meramente incidental o tangencial ${ }^{14}$. Pero no sólo las ordenanzas, también los propios reglamentos orgánicos municipales tienen en ocasiones eficacia ad extra y afectan a los derechos de los particulares, lo que acaece no sólo cuando tales normas se ocupan de los servicios públicos locales sino también cuando regulan, por ejemplo, el régimen de acceso a la información de los archivos y registros administrativos municipales ${ }^{15}$.

Pero esta expansión del poder normativo local se ha visto frenada, en cierto modo, por dos fenómenos recientes: la aprobación de leyes (en particular autonómicas) sobre muchas de las materias que las ordenanzas habían procedido a regular y el indisimulado intento de la Ley de Racionalización y Sostenibilidad de la Administración Local de 2013 de reducir las competencias locales y, por consiguiente, el poder normativo local.

En efecto, numerosas leyes estatales y autonómicas se han ocupado en los últimos años de materias que previamente habían sido reguladas por ordenanzas municipales, a las que han venido a dotar de una cobertura legal de la que inicialmente carecían. Así ha ocurrido, por poner sólo algunos ejemplos, en materia de «contaminación acústica» con la Ley 17/2003, de 17 de noviembre, del Ruido o con la Ley 16/2002, de 28 de junio, de Contaminación Acústica de Cataluña; en el ámbito de la "contaminación lumínica» con la Ley Foral 10/2005, de 9 de noviembre, sobre la ordenación del alumbrado para la protección del medio nocturno; en materia de «energía solar» con la legislación estatal de telecomunicaciones (Leyes 32/2003, de 3 de noviembre, y 9/2014, de 9 de mayo); en lo que respecta al «botellón» con la Ley 5/2002, de 27 de junio, sobre Drogodependencias y otros Trastornos Adictivos de la Comunidad de Madrid, o con la Ley $7 / 2006$, de 24 de octubre, sobre potestades administrativas en materia de determinadas actividades de ocio en los espacios abiertos de los Municipios de Andalucía; con los «animales peligrosos» con la Ley andaluza 50/1999, de 23 de diciembre, sobre el régimen jurídico de la tenencia de animales potencialmente peligrosos; o en el ámbito de la «movilidad» con las Leyes de movilidad de Cataluña (Ley 9/2003, de 19 de junio), de Valencia (Ley 6/2011, de 1 de abril), de Baleares (Ley 4/2014, de 20 de junio) o de Asturias (Ley 12/2018, de 23 de noviembre).

En segundo lugar, la ampliación del campo material de las ordenanzas se ha visto frenada también con la Ley de Racionalización y Sostenibilidad de la Administración Local, dictada en un contexto de grave crisis económica con la finalidad, dice su propia Exposición de Motivos, de clarificar las competencias locales, evitar duplicidades y racionalizar la organización local. La mayoría de la doctrina y el propio Consejo de Estado (en su dictamen 567/2013) han visto en dicha norma un claro intento de reducción de las competencias municipales. Pero el intento, han destacado otros, es más aparente que real y, en todo caso, ha sido desactivado en cierto modo por el TC.

El intento es más aparente que real porque, como se ha señalado, «la ley mantiene prácticamente intacto el cuadro de las competencias municipales establecido en 1985»y, más bien, «podría decirse que el complejo de competencias locales experimenta una cierta tendencia al crecimiento», como puede apreciarse si se compara la relación de materias que presentaba el art. 25.2 de la LBRL en su redacción originaria y la que presenta ahora tras la reforma llevada a cabo por la Ley de Racionalización y Sostenibilidad ${ }^{16}$. Además, la nueva redacción del art. 25.2 LBRL indica específicamente materias de interés local para que las leyes estatales o autonómicas asignen "competencias propias», algo que la anterior redacción no precisaba ${ }^{17}$.

El intento ha sido desactivado también por el TC al resolver los numerosos recursos de inconstitucionalidad (nueve en total) y los conflictos en defensa de la autonomía local (dos) interpuestos contra la Ley de Racionalización y Sostenibilidad. Así, frente a la pretensión que -según muchos- parecía subyacer en dicha Ley de que el listado de materias del art. 25.2 de la LBRL era de máximos, de modo que el legislador

14 Sobre ello, ORTEGA BERNARDO, J. (2014: 129 y ss.), donde se pueden ver numerosos ejemplos de ordenanzas sobre tales temas.

15 Vid. ORTEGA BERNARDO, J. (2014: 39-40). Sobre los reglamentos orgánicos locales, vid. el completo estudio de GALÁN GALÁN, A. (2004), así como FERNÁNDEZ FARRERES, G. (2011: 1.467 y ss.).

16 SANTAMARÍA PASTOR, J. A. (2014: 141), quien destaca que, en buena parte de los casos, los rótulos competenciales son literalmente idénticos, en algunas materias las alteraciones son puramente terminológicas, en otras el recorte es puramente aparencial (como sucede con la protección del medio ambiente), mientras que en otros casos el recorte es indiscutible (por ejemplo, en la «prestación de servicios sociales y de promoción y reinserción social», que se reduce a «evaluación e información de situaciones de necesidad social y la atención inmediata a personas en situación o riesgo de exclusión social»), pero se restablece el nivel competencial por la vía de las competencias delegadas; por el contrario, en otros ámbitos hay una clara ampliación competencial: infraestructura viaria y otros equipamientos de su titularidad, conservación, mantenimiento y vigilancia de los edificios de titularidad local destinados a educación infantil, primaria o especial, previsión de nuevas competencias delegadas, etc. (págs. 143-145).

17 Vid. CIDONCHA MARTíN, A. (2017: 72). 
sectorial sólo podría atribuir competencias propias en las materias ahí reflejadas, el TC ha considerado (en especial en las SSTC 41/2016, 111/2016 y 107/2017) que el art. 25.2 no establece un numerus clausus, sino solo las materias dentro de las cuáles las leyes estatales y autonómicas deben necesariamente atribuir competencias propias a los Municipios, de modo que el elenco de materias de ese precepto puede ser ampliado también por el Estado o por las CC.AA. en sus propios Estatutos o en su legislación sectorial ${ }^{18}$.

\section{LA POSICIÓN SINGULAR DE LAS ORDENANZAS EN EL SISTEMA DE FUENTES: ¿VINCULACIÓN NEGATIVA A LA LEY?}

\subsection{La posición singular de las ordenanzas y sus manifestaciones más importantes}

Pero en estos 40 años se ha tratado, sobre todo, de enfatizar la posición singular de las ordenanzas en el ordenamiento jurídico. Como las ordenanzas, se afirma, son el producto de un poder normativo originario derivado de la autonomía local que la CE garantiza (SSTC 214/1989, 385/1993, 40/1998, 233/1999, $132 / 2001$, etc.), su posición en el sistema normativo es muy distinta a la de los reglamentos estatales y autonómicos, con los que en modo alguno se les pueden equiparar.

Son varias las expresiones de esa singularidad: las ordenanzas son tipos normativos diferentes a los reglamentos gubernativos, pertenecen a un ordenamiento jurídico propio, no están subordinadas a ninguna otra norma procedente de la misma entidad y responden a la idea de manifestación y desarrollo de un poder propio ${ }^{19}$; las ordenanzas, a diferencia de los reglamentos estatales y autonómicos, no se limitan a desarrollar o ejecutar las leyes, sino que tienen un campo de acción mucho más amplio que les permite adoptar políticas propias, razón por la que su relación con las leyes no se puede reconducir al esquema tradicional ley-reglamento ejecutivo ${ }^{20}$; la ordenación entre las ordenanzas y las leyes es compleja y no sólo se rige por el principio de jerarquía, sino también por el de competencia ${ }^{21}$; la CE contemplaría incluso una reserva de ordenanza o una reserva relativa de regulación local en las materias de interés local ${ }^{22}$.

Algunas de estas singularidades son certeras pero otras resultan cuestionables. Por ejemplo, la de que la relación entre las ordenanzas y las leyes se rige también por el principio de competencia o la de que existe una reserva de ordenanza en la CE. En mi opinión, de la lectura de la CE se extrae claramente la conclusión de que las normas locales no tienen reservado ningún ámbito material, así como que no hay materias que la ley no pueda regular. El que la autonomía local implique la necesidad de una contención del legislador, de modo que no pueda establecer regulaciones agotadoras que la desfiguren o desconozcan por completo, no quiere decir que la CE consagre una reserva de ordenanza en cuyo ámbito la ley no pueda entrar. La ley puede regular cualquier materia, aunque en los asuntos en los que está presente un interés local no pueda hacerlo con la densidad que quiera. La autonomía supone un espacio de decisión propio, pero ese espacio lo determina la propia ley con un amplio margen de apreciación.

En cualquier caso, las dos manifestaciones más generalmente aceptadas hoy de esa posición singular de las ordenanzas en nuestro sistema de fuentes son, sin lugar a dudas, la de que su vinculación a la ley es negativa y la de que en determinados ámbitos la reserva de ley se flexibiliza o modula aún más, de modo que en ellos las ordenanzas tendrían un mayor campo de acción. La idea que subyace se puede sintetizar así: en los asuntos de interés local, «más ordenanza y menos ley».

En este apartado me voy a ocupar únicamente de la (supuesta) existencia de una vinculación negativa general de las ordenanzas a la ley. La flexibilización de la reserva de ley en algunos ámbitos o sectores, los argumentos que se han utilizado para ello y su consistencia, así como la necesidad real de esa mayor flexibilización o modulación de la reserva de ley, en particular en el ámbito sancionador, serán objeto de análisis en el cuarto y último apartado de este trabajo.

18 Sobre el tema, entre otros, MARTíN REBOLLO, L. y ALEGRE ÁVILA, J. M. (2017: 2029); CIDONCHA MARTíN, A. (2017: 63 y ss.).

19 GALÁN GALÁN, A. (2010: 6-7).

20 PAREJO ALFONSO, L. (1998: 80 y ss. y 2016: 160); BLASCO DÍAZ, J. L. (2001: 86); GALÁN GALÁN, A. (2001: 227-230); JIMÉNEZ ASENSIO, R. (2005: 37); ORTEGA BERNARDO, J. (2014: 239); MUÑOZ MACHADO, S. (2015: 283), para quien la relación ley-ordenanza se asemejaría a la que media entre las leyes básicas estatales y las autonómicas de desarrollo. En contra de esto último, VELASCO CABALLERO, F. (2009: 252).

${ }^{21}$ SÁNCHEZ GOYANES, E. (2000: 82, 92); BLASCO DÍAZ, J. L. (2001: 75); BELLO PAREDES, S. E. (2002: 200); ORTEGA BERNARDO, J. (2014: 225-228).

22 SÁNCHEZ GOYANES, E. (2000: 82); VELASCO CABALLERO, F. (2009: 245-246). 


\subsection{La vinculación negativa a la ley y su fundamento}

La concepción hoy dominante en la doctrina, y en la jurisprudencia también, considera, en efecto, que hay una vinculación negativa de las ordenanzas a la ley, de modo que, las ordenanzas sólo tienen en ella límite externo y por eso pueden regular todo lo que no prohíbe sin necesidad de habilitación legal previa: la ley es un límite negativo, la que marca la linde exterior de la ordenanza ${ }^{23}$.

No comparto esta tesis, comenzando por su propio fundamento ${ }^{24}$. Para algunos autores, la vinculación negativa a la ley derivaría del reconocimiento (implícito) del poder normativo local en la propia CE, y se vería refrendado por las numerosas normas que disponen que las ordenanzas se dictan «en el marco» o «de conformidad» con la ley y que lo único que precisan respecto de ellas es que no pueden contener preceptos contrarios a las leyes ${ }^{25}$. Pero si ese fuera el fundamento, también la potestad reglamentaria del Gobierno estaría negativamente vinculada a la ley, ya que es un poder originario que atribuye (además de forma expresa) la propia CE, ha de ejercerse de acuerdo con ella y con las leyes (art. 97), y, en particular, según dispone el art. 22 de la Ley del Gobierno, de conformidad con los principios y reglas contenidos en el Título VI de la LPAC, cuyo art. 128.2 dispone expresamente que los reglamentos tampoco pueden vulnerar la CE o las leyes ni regular materias reservadas a la ley. El que la norma habilitante del poder normativo local sea la propia CE, y deba ejercerse de conformidad con la ley, no significa indefectiblemente que, en todas las materias de interés local, la vinculación de las ordenanzas a la ley sea negativa.

También se esgrime como fundamento de la vinculación negativa de las ordenanzas a las leyes la naturaleza política y no meramente administrativa de la autonomía local y de los gobiernos locales ${ }^{26}$. Pero tampoco este argumento resulta convincente. Para empezar, lo que el TC ha señalado, más bien, es que la autonomía local es administrativa (STC 31/1982, FJ 3); que la autonomía de las CC.AA. tiene «una dimensión política» de la que carecen los Ayuntamientos (STC 11/1999, FJ 4); que los entes locales «son ante todo Administraciones públicas» y su autonomía "es sustancialmente diferente a la de las CC.AA.» (STC 132/2012, FJ 7); y que, aunque son Administraciones de carácter representativo dotadas de autogobierno, su órgano representativo, a diferencia del de las CC.AA., no está separado, sino que es "parte del órgano de gobierno y administración del ayuntamiento o diputación (STC 111/2016, FJ 8). Aunque, en el caso de los Municipios, dicho órgano representativo tiene legitimidad democrática directa, las normas que aprueba no son leyes ni la voluntad general que representa es equiparable a la que expresa un Parlamento autonómico o el estatal. Además, en sentido subjetivo, los entes locales son Administraciones (como acredita el rótulo del capítulo II del Título VIII de la CE), lo que no significa que se limiten a administrar, pues también gobiernan ya que ejercen labores de dirección política y toman decisiones con arreglo a criterios de oportunidad, como hacen también, por lo demás, los órganos superiores y directivos de la Administración del Estado y de las CC.AA. ${ }^{27}$.

El resto de argumentos que también se esgrimen para justificar que las ordenanzas están vinculadas negativamente a la ley, tales como la legitimación democrática directa del órgano que aprueba las ordenanzas o la propia autonomía local de la que las ordenanzas son expresión, tampoco me parece que conduzcan a esa conclusión. La autonomía municipal y el carácter representativo de órgano que las aprueba explican y justifican un campo de acción de las ordenanzas municipales más amplio y extenso que el que corresponde a los reglamentos gubernativos con carácter general, pero no necesariamente dicho tipo de vinculación,

23 En la doctrina, entre otros, GALÁN GALÁN, A. (2001: 179 y 2010: 2 y ss.); BLASCO DÍAZ, J. L. (2001: 191); JIMÉNEZ ASENSIO, R. (2005: 37); VELASCO CABALLERO, F. (2009: 242); EMBID IRUJO, A. (2010: 115, 125); ORTEGA BERNARDO, J. (2014: 197, 246 y ss.); MUÑOZ MACHADO, S. (2015: 283). En la jurisprudencia, por ejemplo, SSTS de 7 de octubre de 2009 (rec. núm. 204/2008), de 14 de febrero de 2013 (rec. núm. 4.118/2011). Vid. también el Dictamen del Consejo de Estado núm. 1.749/1994, de 23 de febrero de 1995.

24 Se muestra radicalmente en contra también y considera que los argumentos que se invocan son insostenibles y producen grave daño para elementos esenciales del Estado de Derecho y la libertad de los ciudadanos, REBOLLO PUIG, M. (2019: 266).

25 Por ejemplo, el art. 3.1 de la Carta Europea de la Autonomía Local (la autonomía local es el derecho y la capacidad efectiva de las entidades locales de ordenar y gestionar una parte importante de los asuntos públicos «en el marco de la ley»); el art. 55 del Texto refundido de las disposiciones legales vigentes en materia de régimen local (las ordenanzas y reglamentos de las entidades locales «en ningún caso contendrán preceptos opuestos a las leyes»); el art. 2.2 de la Ley 22/2006, de 4 de julio, de Capitalidad y Régimen Especial de Madrid (las funciones de ordenación y ejecución se ejercen por el Ayuntamiento bajo su propia responsabilidad y «en el marco de las leyes»); el art. 237.1 del Texto refundido de la Ley Municipal y de Régimen Local de Cataluña («Las ordenanzas y los bandos no pueden contener preceptos contrarios a las leyes y otras disposiciones generales»). Mas ejemplos en GALÁN GALÁN, A. (2010: 14 y ss.).

26 Dictamen del Consejo de Estado 1.794/1994, de 23 de febrero. En la doctrina, GALÁN GALÁN, A. (2010: 10).

27 Es muy claro y convincente al respecto CIDONCHA MARTíN, A. (2017: 30-31), de quien tomo las referencias de la jurisprudencia constitucional y quien, en esa polémica autonomía administrativa-autonomía política de los entes locales, concluye que: «llámese a esto como se quiera (el nombre no altera la naturaleza de las cosas). Yo lo llamo autonomía local, sin más». 
porque, como se verá, ese extenso campo de acción puede darse igualmente aunque las ordenanzas estén positivamente vinculadas a la ley.

Pero, al margen de su discutible fundamento, la tesis de la vinculación negativa a la ley no deja de ser paradójica por cuanto que, como reconocen muchos de los autores que la defienden, es el legislador mismo el que configura la autonomía local y el que delimita o enmarca el contenido del poder de ordenanza mediante la fijación de su ámbito material, por lo que, más que un límite externo o frontera a su libre actuación, la ley constituye el marco y fundamento de su campo de acción. La ley es, cuando menos, el fundamento previo del ámbito material de actuación de las ordenanzas municipales, tal y como disponen expresamente los arts. 7.2 y 4 y 25.2 y 3 de la LBRL ${ }^{28}$.

La autonomía supone un espacio de decisión propio, pero ese espacio lo delimita el legislador ya que no lo ha hecho directamente la propia CE. El que, dentro del espacio delimitado por la ley, el Municipio, en ejercicio de su autonomía, pueda optar libremente por varias opciones políticas no hace que la vinculación a la ley sea negativa o desligada de ella por completo, pues sólo puede moverse dentro del espacio señalado previamente por el legislador.

La tesis general de la vinculación negativa a la ley, en fin, también resulta chocante si se tiene en cuenta la posición central de la ley en la ordenación del sistema de fuentes local, pues, a falta de un criterio constitucional sobre el particular, es la propia ley la que establece las relaciones entre las ordenanzas y los reglamentos estatales y autonómicos y, por tanto, la que determina si se ordenan con arreglo al principio de jerarquía, el de competencia o el de primacía, lo que, como se ha señalado, explicaría la diversidad de resoluciones judiciales al respecto ${ }^{29}$.

\subsection{Vinculación a la ley y amplitud del campo de acción de las ordenanzas municipales}

Pero, al margen de lo cuestionables que resultan los argumentos a favor de la vinculación negativa a la ley y de las paradojas de esa afirmación en un subsistema normativo en el que la ley goza de una posición central, lo que realmente hay que plantearse es, en primer lugar, si el concepto de vinculación negativa determina la extensión del campo de actuación de las ordenanzas municipales y, en segundo lugar, si dicho concepto explica adecuadamente su posición en nuestro ordenamiento.

Con la afirmación de que la vinculación de las ordenanzas a la ley es negativa, a veces, lo que se quiere destacar es que el espacio normativo de las ordenanzas, el alcance real de su poder de innovación y la posibilidad de implantar políticas propias en los asuntos de interés local, resulta mayor que si están positivamente vinculadas a la legalidad, lo cual es erróneo. Otras veces, lo que se quiere significar es que los Ayuntamientos no requieren en ningún caso de habilitación legal previa para aprobar ordenanzas en los asuntos de interés local, lo cual, formulado con esa generalidad, no refleja realmente los datos que actualmente ofrece nuestro Derecho positivo.

Lo primero es erróneo porque el poder innovador de las ordenanzas no depende del tipo de vinculación a la ley, sino de la densidad normativa de ésta, del contenido y extensión de las disposiciones que contiene. En un sistema de vinculación positiva puede haber un amplio campo de acción para las ordenanzas si es vasta y extensa la habilitación legal y, a la inversa, en un sistema de vinculación negativa no hace falta habilitación legal, pero el ámbito de las ordenanzas puede ser muy reducido si la ley regula agotadoramente la materia y el campo que deja a las ordenanzas es muy estrecho. En definitiva: es posible un poder normativo local amplio e innovador en un sistema con vinculación positiva a la ley y, a la inversa, un poder normativo local reducido y poco creador en un sistema donde la vinculación es negativa, pues la clave no es el tipo de vinculación a la ley, sino la densidad normativa de su regulación.

Lo segundo, la tesis de que las ordenanzas no necesitan habilitación legal específica, no refleja los datos del Derecho positivo porque la cuestión se plantea de forma binaria y excluyente (vinculación positiva o

28 Art. 7.2: «Las competencias propias de los Municipios, las Provincias y las Islas y demás Entidades Locales territoriales sólo podrán ser determinadas por Ley...»; art. 25.2: «El Municipio ejercerá en todo caso competencias propias, en los términos de la legislación del Estado y de las Comunidades Autónomas...»; art. 25.3: "Las competencias municipales en las materias enunciadas en este artículo se determinarán por Ley...». Incluso respecto de la cláusula del art. 7.4 (competencias propias genéricas), que permitiría a los Municipios el ejercicio de competencias no atribuidas específicamente (STC 41/2016, FJ 12), el propio párrafo $2 .^{\circ}$ de dicho precepto dispone que: «En todo caso, el ejercicio de estas competencias deberá realizarse en los términos previstos en la legislación del Estado y de las Comunidades Autónomas».

29 VELASCO CABALLERO, F. (2009: 286 y ss.), con numerosos ejemplos de leyes sectoriales que articulan la relación entre los reglamentos gubernativos y las ordenanzas con arreglo a tales criterios. 
vinculación negativa), cuando en algunos ámbitos la vinculación a la ley es positiva mientras que en otros, la mayoría, la vinculación puede considerarse negativa o menor. Veámoslo.

\section{4. Ámbitos que desmienten la vinculación negativa de las ordenanzas a la ley}

Hay ámbitos, en efecto, en los cuales el apoderamiento legal es necesario para que las ordenanzas puedan intervenir o regular un sector: el de las materias reservadas a la ley y el de la limitación de la libertad genérica a los ciudadanos.

En el primer caso, como luego se verá, el TC ha flexibilizado o modulado la reserva en algunos ámbitos (tributario, sancionador) para que el poder regulador de las ordenanzas sea más amplio o mayor que el que corresponde a los reglamentos estatales o autonómicos, pero la necesidad de una ley previa en la materia que delimite el campo de las ordenanzas y precise lo que pueden hacer no se ha eliminado por completo. Es cierto que, en tales casos, podría sostenerse que si la ley tiene una menor densidad normativa para que la ordenanza tenga un mayor poder innovador resultaría innecesario que la ley habilitase expresamente a la ordenanza y se remitiese a ella, pues la habilitación ya estaría implícita en la propia ley, la cual precisamente se contiene o retrae para garantizar la modulación de la reserva. La habilitación estaría implícita, pero sería una habilitación inequívoca al fin y al cabo. En cualquier caso, de la jurisprudencia constitucional se deduce, más bien, la exigencia de que la ley contenga una habilitación expresa a la ordenanza precisando su campo de actuación, lo que no creo que pueda entenderse como un simple reenvío a ellas. Así, por ejemplo, en el ámbito de las Haciendas locales, la STC 233/1999 precisa que, en relación a los tributos propios de las Corporaciones Locales, «la ley deberá reconocerles una intervención en su establecimiento o en su exigencia» $[F J \text { 10.b) }]^{30}$. Y, en el ámbito sancionador, la STC 132/2001 dispone que la ley debe fijar los criterios mínimos de antijuridicidad «que orienten y condicionen la valoración de cada Municipio a la hora de establecer los tipos de infracción [...] y las clases de sanciones que pueden establecer las ordenanzas municipales» (FJ 6). De hecho, en estos ámbitos, las leyes hacen una llamada expresa a las ordenanzas cuyo ámbito de actuación acotan y definen, como puede verse en la propia LBRL (arts. 140 y 141), en la Ley del Ruido (art. 28.5 y art. 29.2) o en el Texto refundido de la Ley de Haciendas locales (art. 15).

En segundo lugar, también debe exigirse habilitación legal siempre que se pretenda restringir o limitar la libertad genérica de los ciudadanos. Como se ha señalado, junto a las reservas específicas de ley, la CE proclama el principio general de que cualquier limitación de la libertad de los particulares producida por un reglamento tiene que estar prevista en una ley, pues en nuestro ordenamiento la ley constituye precisamente una garantía de esa libertad y cualquier restricción de ésta tiene necesariamente que encontrar un fundamento legal ${ }^{31}$. EI TC lo ha señalado en varias sentencias y, hasta donde sé, no ha eliminado, relajado o modulado esta exigencia para las ordenanzas municipales: «el principio general de libertad que la Constitución (art. 1.1) consagra autoriza a los ciudadanos a llevar a cabo todas aquellas actividades que la ley no prohíba o cuyo ejercicio no subordine a requisitos y condiciones determinadas» (SSTC 83/1984, 101/1998, 93/1992, 196/1997, entre otras ). Esta exigencia de ley previa es distinta a la reserva de ley y se satisface con ese apoderamiento o habilitación legal sin exigir, por tanto, que la ley entre a regular la materia ${ }^{32}$. Además, basta con que la ley atribuya potestades limitativas de la libertad, aunque no prevea expresamente reglamentos, pues eso ya, unido a la previsión genérica que se deduce de la propia CE y establece el art. 4.1 LBRL, permite establecer límites por reglamentos u ordenanzas ${ }^{33}$.

Es cierto que en la jurisprudencia ordinaria parece ir afianzándose de forma progresiva la tesis de la vinculación negativa, pero también hay algunas sentencias que la desmienten y avalan la exigencia de habilitación legal previa para limitar la libertad de los ciudadanos. La STS de 7 de noviembre de 2012 (rec. núm. 5.582/2010), por ejemplo, confirma la STSJ de Madrid, de 17 de junio de 2010, que declaró nulo el

30 Vid. FERNÁNDEZ-MIRANDA FERNÁNDEZ-MIRANDA, J. (2015: 247, 256).

31 BAÑO LEÓN, J. M. a (1991: 106, 199 y ss. y 2018: 397); REBOLLO PUIG, M. (1991: 98, 112-113 y 2019: 248, 266); SANTAMARÍA PASTOR, J. A. (1991: 202, 781, 850 y 2018: 233, 261-262), GARCÍA DE ENTERRÍA, E. y FERNÁNDEZ RODRÍGUEZ, T. R. (2017: 273 y ss.); BELADÍEZ ROJO, M. (2000: 333, 337); entre otros.

32 Aunque es un tema discutido, y la doctrina está dividida al respecto, la previsión genérica del art. 84 LBRL («las Corporaciones locales podrán intervenir la actividad de los ciudadanos a través de ... ordenanzas»), no sería suficiente. Un resumen de las tesis mantenidas, con una toma de postura particular (dicho precepto sólo constituye una habilitación de las potestades de policía, mientras que cualquier otra potestad de limitación necesita atribuciones legales específicas), en REBOLLO PUIG, M. e IZQUIERDO CARRASCO, M. (2007: 2.171 y ss.).

33 Vid. REBOLLO PUIG, M. (2019: 156 y 248). 
art. 10 de la Ordenanza de limpieza de los espacios públicos y de gestión de residuos del Ayuntamiento de Madrid porque obligaba a limpiar las aceras en una anchura mínima de dos metros a quienes habitasen en el edificio, desarrollasen la actividad si se tratase de comercios o fueren propietarios en el caso de solares sin edificar, lo que supone trasladar la obligación propia de ese servicio púbico (obligatorio) a los particulares sin mediar una ley previa como exige el art. 31.3 de la CE ${ }^{34}$. La STS 14 febrero de 2013 (rec. núm. 4.118/2011) anuló un precepto de la Ordenanza municipal de civismo y convivencia del Ayuntamiento de Lleida, de 8 de octubre de 2010, que prohibía portar un velo integral en los locales públicos de titularidad municipal porque se restringía un derecho fundamental (la libertad religiosa) sin una decisión previa del legislador. Su razonamiento es el siguiente: la admisión del principio de vinculación negativa de las ordenanzas municipales a la ley «no autoriza a prescindir del hecho de que tal vinculación negativa existe, vinculación que comienza por la Constitución (art. 9.1 y 53.1 CE); y, ello sentado, si la Constitución exige para poder limitar el ejercicio de un derecho fundamental (como lo es el de libertad religiosa, del art. $16 \mathrm{CE}$ ) la existencia de una Ley (art. 53.1, inciso segundo) no se atiene a ese principio de vinculación negativa una Ordenanza que directamente prescinde de la exigencia del art. 53.CE, arrogándose la potestad de regular lo que la Constitución reserva a la Ley» ${ }^{35}$. Pero la argumentación de la sentencia desmiente el punto del que parte, pues la vinculación negativa a la CE se traduce precisamente en una vinculación positiva a la ley en las materias que le reserva la CE.

Fuera de los referidos ámbitos (materias reservadas a la ley y limitación de la libertad genérica de los ciudadanos), puede sostenerse que la vinculación a la ley es negativa, lo que deja un amplio campo de acción a las ordenanzas municipales, las cuales, con la sola base de su atribución genérica (arts. 137 y 140 CE y art. 4 LBRL) pueden ocuparse con un amplio poder de configuración de un extenso número materias, que se puede sintetizar así: la propia estructura organizativa municipal y el funcionamiento de sus órganos, la regulación de los servicios locales (deportivos, educativos, de transportes, etc.), la regulación del uso de sus bienes, la actividad de fomento, la actividad empresarial, etc. ${ }^{36}$.

En cualquier caso, conviene no olvidar que ese tipo de vinculación negativa a la ley en los referidos ámbitos nunca será similar a la de los ciudadanos, cuyo punto de partida es precisamente la libertad genérica, el poder hacer todo lo que la ley no prohíbe, así como el libre desarrollo de la personalidad, que les permite tomar decisiones libres y arbitrarias. Creo que no debe olvidarse que la vinculación negativa a la ley, en los ámbitos en los que opera, nunca podrá ser igual para los Municipios, o para cualquier otra Administración pública, que para los sujetos privados, pues ni tienen la misma posición ante el Derecho ni el Derecho por el que se rigen es el mismo ni para unos y otros sujetos ese distinto Derecho tiene el mismo sentido y significación.

\section{LA FLEXIBILIZACIÓN DE LA RESERVA DE LEY}

\subsection{Sectores en los que se ha flexibilizado la reserva de ley: los tributos locales y las sanciones administrativas}

Paso a referirme, por último, a la relación entre las ordenanzas y las reservas constitucionales de ley. Hay un exponente extremo de esta relación que postula que, en el ámbito local, la reserva de ley se cumpliría precisamente con las ordenanzas municipales en cuanto que son expresión de la autonomía local y son aprobadas por un órgano elegido democráticamente ${ }^{37}$. En las materias reservadas, se viene a decir, «las ordenanzas son la ley».

Pero la tesis que finalmente ha triunfado, como se sabe, es la que modula, flexibiliza o reduce (aún más) la reserva de ley en el ámbito tributario y sancionador para que las ordenanzas puedan tener un mayor campo de acción. En otros ámbitos, como el estatuto de la propiedad del suelo o la libertad de empresa, no se ha considerado necesaria limitar más la reserva de ley que la CE también establece (arts. 33.2, 38 y 53.1)

34 ORTEGA BERNARDO, J. (2014: 54-55) considera discutibles tales sentencias porque la obligación que impone la ordenanza no es una prestación pública individualizada, sino una carga que deriva el derecho de propiedad y que encontraría base legal en el antiguo art. 9.1 del Texto refundido de la Ley del suelo de 2008 (actual art. 15 del texto refundido de 2015). Pero esta autora no repara en que el deber de limpieza que establece la ordenanza recae sobre las aceras, que son bienes de dominio púbico de titularidad municipal, lo que en modo alguno se puede equiparar al deber de mantener limpias las fachadas de los edificios de los que el ciudadano es propietario o titular.

35 En cualquier caso, como puede verse, lo afectado es la libertad religiosa y no la libertad genérica de los ciudadanos y la cuestión se refiere más a la reserva de ley que a la vinculación positiva a la ley.

36 REBOLLO PUIG, M. (2019: 266-267).

37 PAREJO ALFONSO, L. (1998: 83 y ss.). 
dada su menor intensidad; es decir, porque en tales campos la reserva de ley es lo suficientemente reducida o flexible como para garantizar la autonomía local ${ }^{38}$.

En el ámbito tributario, la STC 19/1987 señaló ya que el principio de reserva de ley en la materia «no deberá extenderse hasta un punto tal en que se prive [a los Municipios] de cualquier intervención en la ordenación del tributo o en su exigencia para su propio ámbito territorial», mientras que la STC 185/1995 precisó que cuando se trata de tributos locales el legislador puede «hacer una parcial regulación de tipos, predisponiendo criterios o límites para su ulterior definición por las corporaciones locales a las que corresponderá el tipo que haya de ser aplicado». Pero es en la sentencia 233/1999, ya citada, donde el TC afirma expresamente que la reserva de ley tributaria es más limitada en relación con las ordenanzas locales que con los reglamentos gubernativos, ya que la previsión del art. 31.3 CE no puede entenderse desligada de las condiciones propias del sistema de autonomías que la propia CE consagra, de modo que la autonomía local también posee una proyección en el terreno tributario que se traduce en que las corporaciones locales «habrán de contar con tributos propios y sobre los mismos deberá la Ley reconocerles una intervención en su establecimiento o en su exigencia, según previenen los arts. 140 y 133.2 de la misma Norma Fundamental». El TC también precisa que el alcance de dicha reserva depende del tipo de tributo (la reserva de ley es más flexible aún en las tasas) y del elemento del tributo de que se trate (hecho imponible, base, tipo de gravamen, cuota, etc.) y concluye que «la potestad de fijar la cuota o tipo de sus propios tributos dentro de los límites de la ley es uno de los elementos indiscutiblemente definidores de la autonomía local, encontrándose, como tal, reconocida en el artículo 9.3 de la Carta Europea de la Autonomía Local» ${ }^{39}$. En cualquier caso, y como puede verse por ejemplo en las SSTC 63/2003 (FJ 4) y 150/2003 (FJ 3), esa mayor relativización de la reserva en función del tipo de tributo o de los elementos que lo componen no sólo tiene lugar en relación a las ordenanzas fiscales, sino también respecto de los reglamentos gubernativos.

En el ámbito sancionador, tras una larga discusión doctrinal y una jurisprudencia contradictoria, la STC 132/2001 (que resuelve el recurso de amparo presentado por un taxista contra una sanción que le había impuesto el Ayuntamiento de Madrid de conformidad con su ordenanza de autotaxis) señaló que, en el ámbito local, no es necesario que la ley contenga todos los «elementos esenciales de la conducta antijurídica y la naturaleza y límites de las sanciones a imponer» (como se exige con carácter general), sino que sólo tiene que «fijar los criterios mínimos de antijuridicidad conforme a los cuales cada Ayuntamiento puede establecer los tipos de infracciones» y «las clases de sanciones que pueden establecer las ordenanzas municipales». Respecto de las infracciones, no se trata, dice el TC, de la definición de tipos - ni siquiera de la fijación de tipos genéricos de infracciones que luego deba completar la ordenanza municipal- sino de criterios que orienten y condicionen la valoración de cada Municipio a la hora de establecer tipos de infracción. En cuanto a las sanciones, tampoco se exige que la ley establezca una clase específica de sanción para cada grupo de ilícitos, sino una relación de las posibles sanciones que cada ordenanza municipal puede establecer en función de la gravedad de los ilícitos administrativos que ella misma tipifique. Lo reservado a la ley se limita porque no se exige que la ley tipifique cada tipo de ilícito y su correspondiente sanción, pero no permite la inhibición del legislador ya que las ordenanzas no pueden tipificar infracciones y sanciones sin una base legal previa que presente al menos ese contenido.

Esta jurisprudencia (reiterada luego en las sentencias 161/2003, 6/2004, 232/2006, entre otras) motivó, como se sabe, la introducción de un nuevo Título XI en la LBRL y la modificación de los arts. 127 y 129 de la Ley 30/1992 (hoy arts. 25 y 27 de la LRJSP) ${ }^{40}$. El referido Título XI de la LBRL, que consta únicamente de los arts. 139 a 141, trata de fijar esos criterios mínimos de antijuridicidad a que alude la jurisprudencia constitucional, es decir, el injusto o juicio de desvalor a la conducta del sujeto, y los límites de las sanciones pecuniarias que las ordenanzas pueden prever en defecto de normativa sectorial específica ${ }^{41}$.

38 Sobre la flexibilización de la reserva de ley en tales ámbitos, MUÑOZ MACHADO, S. (2015: 289 y ss.); VELASCO CABALLERO, F. (2009: 275 y ss.); ORTEGA BERNARDO, J. (2014: 110 y ss.). Para el estatuto de la propiedad del suelo vid., ya antes, BAÑO LEÓN, J. M. ${ }^{a}$ (1991: 138 y ss.).

39 Vid. MUÑOZ MACHADO, S. (2015: 295-298); VELASCO CABALLERO, F. (2009: 258-259).

40 El art. 25 de la LRJSP dispone ahora que «la potestad sancionadora de las Administraciones Públicas se ejercerá cuando haya sido expresamente reconocida por una norma con rango de Ley [...] y, cuando se trate de Entidades Locales, de conformidad con lo dispuesto en el Título XI de la Ley 7/1985, de 2 de abril», Reguladora de las Bases de Régimen Local, mientras que el art. 27 de LRJSP añade que sólo constituyen infracciones las vulneraciones del ordenamiento previstas como tales por una Ley «sin perjuicio de lo dispuesto para la Administración Local en el Título XI de la Ley 7/1985, de 2 de abril». En realidad, no es sólo sin perjuicio de lo previsto en la LBRL, sino de lo eventualmente dispuesto en cualquier otra ley sectorial (autonómica o estatal).

41 Sobre el tema, me remito a mis trabajos citados en la bibliografía, y a las obras que cito en ellos. 


\subsection{Los argumentos esgrimidos para flexibilizar (aún más) la reserva de ley y su falta de consistencia}

Los argumentos utilizados para flexibilizar (aún más) la reserva de ley en tales ámbitos son de sobra conocidos: fundamentalmente, la legitimación democrática directa del órgano que aprueba las ordenanzas y el principio de autonomía local constitucionalmente garantizado ${ }^{42}$. A mí no me convencen y, en mi opinión, ninguno de ellos permite respaldar la solución a la que se ha llegado, sobre todo en el ámbito sancionador.

No puede discutirse que el órgano que aprueba las ordenanzas municipales no es equiparable, dado su carácter representativo y la legitimación democrática directa de quienes lo forman, con los órganos que tienen atribuida la potestad reglamentaria en el ámbito autonómico y estatal. Las ordenanzas, por esa razón y por el mayor campo de acción en el que necesariamente han de desenvolverse como consecuencia de la autonomía local, tampoco son del todo comparables a los reglamentos gubernativos. Pero los plenos de los Ayuntamientos tampoco son equiparables a los Parlamentos ni las ordenanzas a las leyes.

Las ordenanzas municipales, a pesar de emanar de un órgano elegido democráticamente como las leyes, poco tienen que ver con ellas. El procedimiento de elaboración no es el mismo, la posibilidad de conocimiento por los ciudadanos tampoco y, desde luego, la voluntad popular que expresa el órgano que aprueba las ordenanzas y las leyes no tiene parangón ${ }^{43}$. Las ordenanzas no pueden equipararse a las leyes porque no son expresión de un pueblo en el sentido en que se utiliza esta expresión desde el prisma del principio democrático. Como se ha señalado, el concepto constitucional de democracia se refiere al pueblo y al parlamento que lo representa (que en los Estados federales también pueden ser los parlamentos de los Estados o de las CC.AA.), pues de ese modo se garantiza que sus decisiones representen una colectividad amplia y determinada con arreglo a unas características generales, lo que evita intereses sectoriales, locales o de grupo y garantiza una cierta distancia, objetividad o imparcialidad en el órgano que adopta las decisiones, lo que constituye una forma de proteger al ciudadano, razón por la cual deben desecharse planteamientos como los que consideran que cualquier norma que proceda de un órgano colegiado elegido democráticamente se encuentra tan legitimada como una ley y debería ser apta para regular la materias reservadas a la misma ${ }^{44}$. El preámbulo de nuestra CE es claro cuando declara que sólo la ley es expresión de la voluntad popular.

Tampoco está justificada la equiparación desde el punto de vista del fundamento actual de las reservas de ley, pues, aunque con carácter general se entienda que reside en el procedimiento de elaboración de la norma, el cual asegura la transparencia y la publicidad, el debate y una participación amplia y plural donde se respetan las minorías, no debe perderse de vista el órgano al que la CE atribuye la aprobación de las normas con rango de ley idóneas para cumplir la reserva constitucional. Y es que, en rigor, la CE no ha querido que la reserva de ley se cumpla por cualquier norma aprobada por un órgano con legitimación democrática directa o que siga un procedimiento público y plural, sino por quienes pueden aprobar leyes (los parlamentos) o normas con rango de ley (el Gobierno y los ejecutivos autonómicos).

El segundo argumento que se utiliza es el de la autonomía local constitucionalmente garantizada. Pero, como ya se ha señalado, en puridad, a lo que el principio constitucional de autonomía local conduce, en perjuicio del legislador autonómico o estatal, es a la necesidad de que las ordenanzas cuenten con un amplio campo de regulación en aquellos ámbitos en los que dicha autonomía está realmente presente, lo que se traduce en que la relación (en lo que a la densidad normativa se refiere) entre las leyes y las ordenanzas municipales sea diferente a la existente entre la ley y los reglamentos estatales o autonómicos. Si en los asuntos

42 Respecto de las sanciones también se ha utilizado el argumento histórico: la tipificación de infracciones y sanciones en las ordenanzas, se afirma, es tan antigua como los propios Municipios. Vid. el dictamen del Consejo de Estado de 23 de febrero de 1995. En la doctrina, NIETO GARCÍA, A. (2012: 85). El argumento histórico o de presunción de continuidad constituye uno de los tipos de razonamiento utilizado por los juristas para interpretar los textos legales, pero no puede ser empleado para contradecirlos. En el caso que nos ocupa no es de aplicación porque la modificación que la CE ha llevado a cabo respecto de la regulación anterior es clara al exigir una reserva de ley en la materia. Además, conduciría al absurdo, no ya sólo en el ámbito local sino también en el estatal, de admitir que los simples reglamentos gubernativos tipifiquen infracciones y sanciones ya que esa ha sido la tradición histórica en la materia.

43 Como dijo hace años FERNÁNDEZ RODRÍGUEZ, T. R. (1995: 223-224) es cierto que las ordenanzas son normas aprobadas «por órganos representativas de la voluntad popular, pero habría que preguntar de la voluntad popular ¿de qué? Porque no parece que los vecinos de un Municipio cuando eligen a sus ediles tengan una efectiva voluntad de confiarles la protección y custodia de sus vidas, haciendas y libertades, que es precisamente la materia propia de las Leyes. (...) De Isonomía, más que de democracia, se habló en la Grecia clásica al referirse a las Leyes». A lo que añade que «ocho mil voluntades generales equivalen a una voluntad general por cada 4.500 españoles, niños incluidos. ¡Demasiadas voluntades y demasiado poco generales!».

44 HUERGO LORA, A. (2007: 374). 
de interés municipal, para cuya gestión los Municipios gozan de autonomía, las leyes llevaran a cabo una regulación tan completa o agotadora como la que pueden realizar en las materias en las que dicho interés no está presente, la autonomía municipal quedaría vacía de contenido y no podría hablarse realmente de tal.

Por eso llevan razón quienes afirman que la potestad de ordenanza no puede ser considerada como una mera potestad de ejecución de las leyes o como una potestad reglamentaria general sin ninguna característica especial ${ }^{45}$. Pero esto, a lo que conduce, realmente, es a que las leyes no puedan contener una regulación completa y acabada cuando está presente el interés local, lo cual, en efecto, ni puede hacerse ni es necesario que se haga porque, en realidad, las reservas de ley no son absolutas y ya están moduladas o flexibilizadas.

Además, la (mayor) modulación de la reserva en tales ámbitos no deja de plantear problemas. Por ejemplo: ¿es un mandato o una permisión? Es decir, es algo obligado para el legislador o es una simple opción que puede desconocer. Si se quiere ser coherente con los argumentos que llevan a esa mayor relajación, el legislador no debería gozar de poder de disposición para modular o no la reserva, sino que debería respetar siempre esa necesidad de mayor flexibilización. Sin embargo, no es eso lo que hacen muchas leyes. Baste ver la extensa regulación de los tributos locales en el Texto refundido de Ley de Haciendas Locales (cuyos arts. 61 y ss. prevén casi todo en relación al hecho imponible, exenciones, sujeto pasivo, base imponible y liquidable, cuota y tipo de gravamen del Impuesto de Bienes Inmuebles, del de Actividades Económicas y del de Vehículos de Tracción Mecánica) o lo que ha hecho recientemente en el ámbito sancionador la Ley de Seguridad Ciudadana, cuyo art. 32.3 dispone que «las ordenanzas municipales podrán introducir especificaciones o graduaciones en el cuadro de las infracciones y sanciones tipificadas en esta ley» ${ }^{46}$.

\subsection{La flexibilización de la reserva de ley en el ámbito sancionador y su carácter innecesario}

Como es de sobra conocido, nuestro ordenamiento jurídico prevé diferentes clases de reserva de ley, no todas con el mismo alcance y extensión. Pero todas ellas, salvo quizá la prevista para el ámbito penal, son relativas o flexibles, por lo que, según la interpretación que de ellas se ha hecho, permiten la colaboración del reglamento en la regulación de la propia materia reservada. En algunos ámbitos, las reservas de ley son incluso muy dúctiles y limitadas, lo que permite la existencia de reglamentos que no se limitan simplemente a ejecutar y desarrollar la ley, y explica, en buena medida, el que más del $90 \%$ de las normas escritas de nuestro ordenamiento sean de carácter reglamentario. Por eso, en mi opinión, la mayor flexibilización aun de la reserva de ley en algunos ámbitos, en particular en el ámbito sancionador, en el que se ha desfigurado por completo, ni está justificada ni era necesaria para garantizar la autonomía local.

No está justificada por la debilidad de los argumentos en que se apoya para ello y, además, porque, vulnerando la regla de la ponderación que a veces se esgrime, sacrifica en exceso los bienes y valores que subyacen en la reserva de ley sin obtener una correlativa satisfacción de la autonomía local. Y resulta innecesaria porque, aunque efectivamente la autonomía local exige que en los asuntos de interés local las ordenanzas cuenten con un amplio campo de regulación, en el ámbito sancionador eso quedaba garantizado con la técnica de las normas sancionadoras en blanco y con la utilización en los tipos de infracción de conceptos jurídicos indeterminados, que hacen perfectamente compatible la autonomía local con la reserva de ley ${ }^{47}$.

El caso de las leyes sancionadoras en blanco es claro. Como se sabe, se trata leyes sancionadoras cuyo supuesto de hecho o parte del mismo se encuentra en una norma (reglamentaria) distinta que establece mandatos y prohibiciones pero no tiene carácter sancionador. El recurso generalizado a ellas en el ámbito local estaría justificado por la especial relación de la ley y las ordenanzas que deriva del principio de autonomía local, esto es, por la referida circunstancia de que las ordenanzas no se pueden limitar a desarrollar o ejecutar la ley, sino que deben poder establecer disposiciones con menos ataduras y más completas y acabadas en los ámbitos de interés local.

El contenido material mínimo de la ley debería traducirse, al menos, en una descripción precisa del comportamiento reputado ilícito, lo cual entronca ya con la vertiente material del principio de legalidad (ti-

45 NIETO GARCÍA, A. (2012: 290); CARRO FERNÁNDEZ-VALMAYOR, J. L. (2004: 135); MUÑOZ MACHADO, S. (2005: 1.472).

46 Vid. la convincente crítica que hace a esta regulación, ALARCÓN SOTOMAYOR, L. (2019: 281 y ss.).

47 Por eso, desde la perspectiva que sostiene que en los ámbitos reservados a la ley «el legislador puede remitirse al reglamento siempre que haya una causa objetiva que lo justifique», la mayor flexibilización aún de la reserva de ley en el ámbito sancionador tampoco era necesaria y, por tanto, no está justificada. Sobre la idoneidad de la remisión al reglamento siempre que haya una causa que lo justifique, BAÑO LEÓN, J. M. ${ }^{a}$ (1991: 101); DOMÉNECH PASCUAL, G. (2006: 199). 
picidad). Por ejemplo, incumplir las normas de conducta previstas en las ordenanzas sobre la ocupación y uso de los espacios públicos, sobre el uso de las vías públicas con vehículos de motor, sobre paradas y el estacionamientos de vehículos, el incumplimiento de los valores límites aplicables en materia de contaminación acústica, la degradación del entorno urbano, el comercio no autorizado etc., lo que el TC denomina «el desvalor de las conductas consideradas ilícitas». La ley también debería contener el modo en que dicho comportamiento afecta al bien jurídico protegido (que pongan en peligro la convivencia, que pongan en riesgo la seguridad vial, que dañen las infraestructuras y espacios públicos, que alteren el funcionamientos de los servicios públicos, que sean nocivas para el medio ambiente, etc.), así como la naturaleza y los límites de las sanciones que proceda imponer.

No bastaría, pues, con una previsión genérica y puramente formal de que constituye infracción administrativa el incumplimiento de cualesquiera normas de conducta contenidas en las ordenanzas municipales. Pero ese contenido mínimo, que se viene exigiendo cada vez de forma más laxa, y que en este caso está plenamente justificado, puede, sin merma alguna para la autonomía local, contemplarse perfectamente en las diferentes leyes (estatales o autonómicas) atributivas de competencias en cada sector o en la propia legislación general de régimen local.

Las ordenanzas municipales, dentro de los límites marcados por las leyes sectoriales o por la propia legislación de régimen local, regularían la materia en cuestión con plena autonomía y en atención a los diversos y heterogéneos intereses locales presentes en cada Municipio (tan diferentes entre sí), estableciendo de forma completa y detallada los distintos supuestos de hecho de las normas sancionadoras en blanco, concretando con precisión y claridad los conceptos jurídicos indeterminados previstos en las leyes y determinando, dentro de los límites legales establecidos, las concretas sanciones a imponer. De esta forma, el incumplimiento de los preceptos contenidos en las ordenanzas municipales encontrarían en la propia ley la adecuada reacción sancionadora, respetándose de este modo la reserva de ley y el principio de autonomía municipal ${ }^{48}$.

Ello permitiría, además, un trato más igualitario de todos los ciudadanos, así como un conocimiento más accesible a los destinatarios de las normas, pues es evidente que resulta más fácil y seguro para los ciudadanos que la tipificación de las infracciones y sanciones se encuentren en normas con rango de ley que en las innumerables y variadas ordenanzas que pueden aprobar nuestros más de ocho mil Municipios.

\subsection{El poder de ordenanza y la crisis de la ley}

Soy consciente de que muchas de las ideas que acabo de expresar están muy alejadas de la concepción hoy dominante sobre la autonomía local y de la idea de que el Municipio es la instancia en la que la democracia es más auténtica. Pero, como recientemente se ha señalado, con todas las salvedades que se quiera, «los Municipios no dejan de ser una instancia de dominación más sobre los ciudadanos: una pieza del entramado de estructuras públicas servida por políticos que son los últimos vasos capilares de los respectivos partidos y por funcionarios que en muy poco se diferencian de los que trabajan en instancias territorialmente superiores, y alimentada por los impuestos; son, en definitiva, instrumentos de poder sustancialmente idénticos a las provincias, las comunidades autónomas y el Estado» ${ }^{49}$.

En mi opinión, no resulta aceptable que las ordenanzas se consideren nulas de pleno derecho cuando falta en su procedimiento de elaboración un simple informe ministerial y, por el contrario, se considere que respetan la CE y el resto de la legalidad cuando restringen claramente la libertad de los ciudadanos sin una ley previa que expresamente lo autorice. Como tampoco me parece de recibo que, en los asuntos de interés local, la reserva de ley de las infracciones y sanciones que consagra el art. 25.1 de la CE se haya diluido por completo y, por mucho que ello se quiera revestir de una simple modulación o flexibilización, se considere cumplida con las vagas y genéricas previsiones de los arts. 139 y 140 de la LBRL que, en realidad, permiten a las ordenanzas municipales tipificar como infracción y castigar con multas de hasta 3.000 euros cualquier comportamiento imaginable.

48 Como señaló HUERGO LORA, A. (2007: 376-377), es cierto que los problemas prácticos que aducen para justificar que las ordenanzas puedan tipificar infracciones y sanciones, como la necesidad de proteger a los vecinos contra el ruido, garantizar la convivencia vecinal, etc., «son problemas absolutamente reales y necesitados de soluciones urgentes y eficaces pero no apuntan tanto a la necesidad de reconocer ese poder a las ordenanzas cuanto a la urgencia de corregir la desidia de los legisladores, sobre todo los autonómicos, que deberían regular esas materias y enmarcar la actuación de los Ayuntamientos».

49 SANTAMARÍA PASTOR, J. A. (2014: 146). 
Creo, en definitiva, que la expansión del poder normativo local es una muestra más de la actual crisis de la ley, que no sólo se manifiesta en la hipertrofia legislativa, en la volatilidad y progresiva pérdida de la fuerza y eficacia de la ley, o en su utilización con fines simbólicos o propagandísticos, sino también, y sobre todo, en el desconocimiento de la mayor parte de los rasgos o propiedades que tradicionalmente se le han atribuido, pues nuestras leyes ya no son emanación del soberano, sino de las más diversificadas y variopintas instancias de poder (globales, supranacionales, regionales, locales, sociales), ya no constituyen la expresión un órgano legislativo o de otro equiparable, sino producto muchas veces de un auténtico «mercado de las leyes», ni gozan de las características formales de la generalidad y la abstracción ni, en fin, constituyen ya las únicas normas que determinan y afectan a los derechos básicos de libertad y propiedad o imponen las cargas a los ciudadanos ${ }^{50}$.

Frente a la atomización del ordenamiento actual, y desde la perspectiva de la igualdad de los ciudadanos y de la necesaria seguridad y previsibilidad del Derecho por parte de todos, desde cuya óptica también hay que analizar la cuestión del poder normativo local, la conclusión debe ser otra bien distinta a la que se está imponiendo en la actualidad: menos ordenanzas y más ley.

\section{BIBLIOGRAFÍA}

ALARCÓN SOTOMAYOR, L. (2019): "Las ordenanzas de convivencia y su relación con la Ley de seguridad ciudadana: quién desplaza a quién", en Revista Galega de Administración Pública (REGAP), núm. 57, págs. 281309. DOI: https://doi.org/10.36402/regap.v1i57.15.

BAÑO LEÓN, J. M. ${ }^{a}$ (1991): Los límites constitucionales de la potestad reglamentaria: remisión normativa y reglamento independiente en la Constitución de 1978. Madrid: Servicio de Publicaciones de la Facultad de Derecho de la Universidad Complutense, Civitas.

BAÑO LEÓN, J. M. ${ }^{a}$ (2011): "La ordenación de las normas reguladoras del régimen local", en MUÑOZ MACHADO, S. (dir.): Tratado de Derecho Municipal, Tomo I, págs. 643-716. Madrid: lustel. 3. ${ }^{a}$ ed.

BAÑO LEÓN, J. M. ${ }^{a}$ (2018): "La potestad reglamentaria”, en RODRÍGUEZ-PIÑERO Y BRAVO FERRER, M. y CASAS BAAMONDE, M. ${ }^{a}$ E. (dirs.): Comentarios a la Constitución Española, Tomo II. Artículo 66 a Disposición final, págs. 393-401. Madrid: Boletín Oficial del Estado BOE, Fundación Wolters Kluwer.

BELADIEZ ROJO, M. (2000): “La vinculación de la Administración al Derecho”, en Revista de Administración Pública, núm. 153, págs. 315-349. URL: http://www.cepc.gob.es/publicaciones/revistas/revistaselectronicas?IDR=1\&IDN=1 $51 \& I D A=24338$.

BELLO PAREDES, S. A. (2002): Las ordenanzas locales en el vigente Derecho español: alcance y articulación con la normativa estatal y autonómica. Madrid: Instituto Nacional de Administración Pública (INAP).

BLASCO DÍAZ, J. L. (2001): Ordenanza municipal y ley. Madrid: Marcial Pons.

CANO CAMPOS, T. (2006): Los Ayuntamientos y el tráfico. Madrid: Iustel.

CANO CAMPOS, T. (2014): Las sanciones de tráfico. Cizur Menor, Navarra: Aranzadi. 2. a ed.

CARRO FERNÁNDEZ VALAMAYOR, J. L. (2004): "Sobre la potestad sancionadora municipal", en Cuadernos de Derecho Local (QDL), núm. 6, págs. 131-142. URL: http://repositorio.gobiernolocal.es/xmlui/handle/10873/162.

CASADO CASADO, L. (2007): "La potestad normativa local en materia de contaminación odorífera: la ampliación de las posibilidades de actuación municipal a partir de la Sentencia del Tribunal Supremo STS de 26 de julio de 2006", en Revista Aranzadi de Derecho Ambiental, núm. 12, págs. 151-167.

CASINO RUBIO, M. (2013): "La vida exagerada de las ordenanzas municipales de convivencia ciudadana", en Seminari de Dret Local. Barcelona, del 05 de octubre de 2012 al 14 de junio de 2013, 6. Sesion 15 de marzo de 2013. Barcelona: Federació de Municipis de Catalunya. URL: http://formacio.fmc.cat/09/fitxers/publicacions/2012/ SDL_12-13.pdf.

CIDONCHA MARTÍN, A. (2017): "La garantía constitucional de la autonomía local y las competencias locales: un balance de la jurisprudencia del Tribunal Constitucional”, en Cuadernos de Derecho Local (QDL), núm. 45, págs. 12-100.

DOMENECH PASCUAL, G. (2006): Derechos fundamentales y riesgos tecnológicos: el derecho del ciudadano a ser protegido por los poderes públicos. Madrid: Centro de Estudios Políticos y Constitucionales (CEPC).

EMBID IRUJO, A. (2010): "Ordenanzas y reglamentos municipales", en MUÑOZ MACHADO, S. (dir.): Tratado de Derecho Municipal, Tomo I, págs. 717-778. Madrid: lustel. 3. ${ }^{a}$ ed.

EMBID TELLO, A. E. (2010): Precaución y Derecho. El caso de los campos electromagnéticos. Madrid: Iustel.

FERNÁNDEZ FARRÉRES, G. (2011): "La potestad local en autoorganización: contenido y límites", en MUÑOZ MACHADO, S. (dir.): Tratado de Derecho Municipal, Tomo II, págs. 1.467-1.495. Madrid: Iustel. $3 .^{a}$ ed.

50 LAPORTA SAN MIGUEL, F. J. (2007: 157 y ss.). 
FERNANDEZ-MIRANDA FERNÁNDEZ-MIRANDA, J. (2015): "El principio de legalidad, la vinculación negativa y el ejercicio de la potestad reglamentaria local", en Revista de Administración Pública, núm. 196, págs. 229 -269. URL: https://recyt.fecyt.es/index.php/RAP/article/view/40088.

FERNÁNDEZ RODRÍGUEZ, T. R. (1995): "La potestad reglamentaria de las Corporaciones Locales", en Cuadernos de Derecho Judicial, núm. 29, págs. 203-226.

FERRER BELTRÁN, JORDI y RODRÍGUEZ, J. L. (2011): Jerarquías normativas y dinámica de los sistemas jurídicos. Madrid: Marcial Pons.

GALÁN GALÁN, A. (2000): La carta municipal de Barcelona y el ordenamiento local. Madrid: Marcial Pons.

GALÁN GALÁN, A. (2001): La potestad normativa autónoma local. Barcelona: Atelier.

GALÁN GALÁN, A. (2010): "La consolidación del principio de vinculación negativa en el ámbito local”, en Revista CEMCI (Centro de Estudios Municipales y de Cooperación Internacional), núm. 8, págs. 1-27. URL: https://revista. cemci.org/numero-8/pdf/articulo2.pdf.

GARCÍA DE ENTERRÍA, E. y FERNÁNDEZ RODRÍGUEZ, T. R. (2017): Curso de Derecho Administrativo, Tomo II. Cizur Menor, Navarra: Civitas, Tomson Reuters.

GUASTINI, R. (2010): Le fonti del Diritto. Fondamenti teorici. Milano: Giuffré.

GUILLÉN NAVARRO, N. A. (2018): "El régimen jurídico de la convivencia y de la protección de espacio público", en Revista Aragonesa de Administración Pública, núm. 51, págs. 65-108.

HUERGO LORA, A. (2007): Las sanciones administrativas. Madrid: lustel.

JIMÉNEZ ASENSIO, R. (2005): "Potestad normativa municipal y convivencia ciudadana", en Anuario de Gobierno Local 2005, págs. 27-90. URL: http://repositorio.gobiernolocal.es/xmlui/handle/10873/535.

LAPORTA SAN MIGUEL, F. J. (2007): El imperio de la ley. Una visión actual. Madrid: Trotta.

MARTÍN REBOLLO, L. y ALEGRE ÁVILA, J. M. (2017): "Las competencias locales en la STC 41/2014, de 3 de marzo", en PAREJO ALFONSO, L. J. y VIDA FERNÁNDEZ, J. (coords.): Los retos del Estado y la Administración del Siglo XXI. Libro homenaje al profesor Tomás de la Quadra-Salcedo Fernández del Castillo, Tomo II, págs. 2.015-2.043. Valencia: Tirant lo Blanch.

MELERO ALONSO, E. (2016): "Las ordenanzas locales como instrumento de exclusión social: la regulación que afecta a las personas sin hogar es derecho administrativo del enemigo", en Revista de Estudios de Administración Local y Autonómica (REALA). Nueva Época, núm. 6, págs. 7-26. DOI: https://doi.org/10.24965/reala.v0i5.10384.

MUÑOZ MACHADO, S. (2005): “Ordenanzas locales (delimitación constitucional)", en MUÑOZ MACHADO, S. (dir.): Diccionario de Derecho Administrativo, Tomo II. H-Z, págs. 1.738-1.744. Madrid, lustel.

MUÑOZ MACHADO, S. (2015): Tratado de Derecho Administrativo y Derecho Público General, Tomo VII. El Reglamento. Madrid: Agencia Estatal Boletín Oficial del Estado (BOE).

NIETO GARCÍA, A. (2015): Derecho administrativo sancionador. Madrid: Tecnos. 5 . $^{\mathrm{a}}$ ed.

ORTEGA BERNARDO, J. (2014): Derechos fundamentales y ordenanzas locales. Madrid: Marcial Pons.

PEMÁN GAVÍN, J. M. ${ }^{a}$ (2007): "Ordenanzas municipales y convivencia ciudadana. Reflexiones a propósito de la Ordenanza de Civismo de Barcelona", en Revista de Estudios de la Administración Local y Autonómica (REALA), núm. 305, págs. 12 y ss. DOI: https://doi.org/10.24965/reala.vi305.9356.

PINO, G. (2010): Diritti e interpretazione. Il ragionamento giuridico nello Stato costituzionale. Bologna: II Mulino.

PAREJO ALFONSO, L. (1998): La potestad normativa local. Madrid: Marcial Pons.

PAREJO ALFONSO, L. (2011): Lecciones de Derecho Administrativo. Valencia: Tirant lo Blanch. 4. ${ }^{a}$ ed.

REBOLLO PUIG, M. (1991): "Juridicidad, legalidad y reserva de ley como límites a la potestad reglamentaria del Gobierno”, en Revista de Administración Pública, núm. 125, págs. 7-163.

REBOLLO PUIG, M. (2019): "La potestad reglamentaria", en REBOLLO PUIG, M. y VERA JURADO, D. J. (dirs.): Derecho Administrativo, Tomo I. Conceptos fundamentales, fuentes y organización, págs. 223-266. Madrid: Tecnos. 4. ${ }^{\mathrm{a}}$ ed.

REBOLLO PUIG, M. e IZQUIERDO CARRASCO, M. (2007): “Artículo 84”, en REBOLLO PUIG, M. (dir.) e IZQUIERDO CARRASCO, M. (coord.): Comentarios a la Ley Reguladora de las Bases de Régimen Local, Tomo II. Artículos 46 a 88. Valencia: Tirant lo Blanch.

SANCHEZ GOYANES, E. (2000): La potestad normativa del Municipio español. Ordenanzas, reglamentos, planes urbanísticos, normas. Madrid: El Consultor.

SANTAMARÍA PASTOR, J. A. (1991): Fundamentos de Derecho Administrativo. Madrid: Ceura.

SANTAMARÍA PASTOR, J. A. (2014): "El régimen de competencias locales y el dilema de la esfinge", en SANTAMARÍA PASTOR, J. A. (coord.): La reforma de 2013 del Régimen Local Español, págs. 139-156. Madrid: Fundación Democracia y Gobierno Local.

SANTAMARÍA PASTOR, J. A. (2018): Principios de Derecho Administrativo General, Tomo I. Madrid: Iustel. 5. ${ }^{\mathrm{a}}$ ed.

SARMIENTO RAMÍREZ-ESCUDERO, D. y MORAL SORIANO, L. (2003): "Ordenanzas locales, reserva de ley y reservas democráticas. A propósito de la Sentencia del Tribunal Superior de Justicia de Madrid, de 28 de mayo de 2003", en Cuadernos de Derecho Local (QDL), núm. 3, págs. 120-130. URL: http://repositorio.gobiernolocal.es/ xmlui/handle/10873/82.

SERRANO PASCUAL, A. (2003): "El sistema de fuentes de las entidades locales (I)", en Cuadernos de Derecho Local (QDL), núm. 2, págs. 7-41. URL: http://repositorio.gobiernolocal.es/xmlui/handle/10873/38. 
SERRANO PASCUAL, A. (2003): "El sistema de fuentes de las entidades locales (II)", en Cuadernos de Derecho Local (QDL), núm. 3, págs. 27-55. URL: http://repositorio.gobiernolocal.es/xm/ui/handle/10873/77.

VELASCO CABALLERO, F. (2009): Derecho local. Sistema de fuentes. Madrid: Marcial Pons.

VELASCO CABALLERO, F. (2013): "Títulos competenciales y garantía constitucional de autonomía local en la Ley de Racionalización y Sostenibilidad de la Administración Local", en SANTAMARÍA PASTOR, J. A. (coord.): La reforma de 2013 del Régimen Local Español, págs. 75-136. Madrid: Fundación Democracia y Gobierno Local.

VELASCO CABALLERO, F. (2019): "Elaboración de ordenanzas y Ley de Procedimiento Administrativo Común", en Revista Vasca de Administración Pública (RVAP). Herri-Arduralaritzako Euskal Aldizkaria, núm. 113, págs. 299349. URL: https://www.euskadi.eus/t59auUdaWar/t59aMostrarFicheroServlet?R01 HNoPortal=true\&t59aldR evista $=2 \& t 59$ aTipoEjemplar $=R \& t 59 a$ Seccion $=38 \& t 59$ aContenido $=9 \& t 59$ aCorrelativo $=1 \&$ t59aVersion $=1 \& t 59-$ aNumEjemplar=113. 